UDC: 615.322: 616.36-008.6: 616.361-002

DOI: $10.15587 / 2519-4852.2018 .129642$

\title{
THE SUBSTANTIATION OF THE SELECTION OF MEDICINAL PLANTS AND THEIR RATIONAL APPLICATION IN DISEASES OF THE HEPATOBILIARY SYSTEM
}

\author{
(C) A. Glushchenko, I. Vladymyrova, V. Georgiyants
}

\begin{abstract}
Мета. Метою роботи була розробка методологічних засад з обгрунтування вибору лікарських рослин та фітопрепаратів при захворюваннях гепатобіліарної системи та визначення аспектів їх рачіонального застосування.

Методи дослідження. Дослідження здійснювали иляхом аналізу наукових літературних відомостей $i$ результатів власних експериментальних досліджень з визначення впливу груп рослинних біологічно активних речовин (БАР) на ланки патологічного процесу при захворюваннях печінки та жовчовивідних шляхів.
\end{abstract}

Результати дослідження. Гепатопротектори рослинного походження є достатньо чисельною групою препаратів і становлять понад половину всіх наявних на фармачевтичному ринку гепатопротекторів. Серед популярних лікарських рослин та препаратів на їх основі (моно- та багатокомпонентних) визначають розторопшу плямисту, артишок посівний, рутку лікарську, основними групами діючих речовин в яких є флавоноїди, гідроксикоричні кислоти та алкалоїди відповідно. Хоча насправді спектр лікарських рослин (та груп біологічно активних речовин), щчо застосовуються для профілактики та лікування захворювань гепатобіліарної системи, є набагато шириим. Тому у статті обгрунтовано необхідність розробки алгоритму вибору лікарських рослин для лікування захворювань гепатобіліарної системи, щчо базується на визначенні основних етіологічних та патогенетичних аспектах захворювань печінки та жовчовивідних шляхів, особливостях застосування лікарських рослин, спектр дії яких обумовлений різними групами біологічно активних речовин.

Висновки. На основі наукових відомостей щьоо етіології, основних ланок патологічного процесу та основних клініко-біохімічних синдромів захворювань гепатобіліарної системи представлено основні напрямки лікування даних захворювань рослинними засобами. Обгрунтовано необхідність розроблення методологічних засад з обтрунтування вибору лікарських рослин та фітопрепаратів при захворюваннях гепатобіліарної системи та визначення аспектів їх раціонального застосування. Сформульовано основні принципи застосування лікарських рослин при захворюваннях печінки та жовчовивідних иляхів

Ключові слова: лікарські рослини, методологія вибору, раціональне застосування, гепатопротекторна дія, жовчогінна дія

\section{Introduction}

Diseases of the gastrointestinal tract are fairly widespread throughout the world, and each year in the structure of internal diseases, the proportion of gastroenterological pathology increases. Diagnosis and treatment of diseases of the digestive tract are complicated by the combination of pathology of various organs and systems, since these organs are not only anatomically, but also functionally closely related. Diseases of the gallbladder and the bile-excreting system are the most common among pathology of the gastrointestinal tract and do not have age-specific characteristics, but, according to statistics, women are more prone to development of this pathology than men (the ratio is about 6-10:1). Drug treatment is aimed at reducing pain and dyspeptic manifestations. Today, hepatoprotectors of plant origin are used most often (up to $54 \%$ ), while the proportion of phospholipid preparations is $16 \%$, and other means, in particular synthetic organotherapy drugs and preparations of amino acids, $-30 \%$ of the total number of hepatoprotectors [1].

The main therapeutic directions of phytotherapy in diseases of the hepatobiliary system (HBS) are:

- rehabilitation after chronic acute respiratory diseases and chronic exacerbations;

- prevention of possible relapses of HBS diseases;
- restoration of disturbed metabolic processes in steatosis and steatohepatitis of different etiology, postholecystectomy syndrome, etc.;

- reduced side effects of chemotherapy drugs;

- reduction of the overall reactivity of the organism as a result of adverse environmental factors.

Phytotherapy in case of chronic diseases of the liver and gall bladder (as well as for other chronic diseases) should last, usually for several months. It is desirable, within a few weeks after treatment with one species of plants to switch to the use of another, which shows a similar effect. In case of necessity of prolonged use of choleretics it is expedient to use one drug for no more than 3 weeks, then replace it with another. Also useful are rationalized combinations of medicinal plants [2, 3].

2. Formulation of the problem in a general way, the relevance of the theme and its connection with important scientific and practical issues

It is quite difficult to classify medicinal plants that affect only the liver or only on the bile ducts. The reason is that no plant affects only one active component. There are plants that affect mainly on liver parenchyma, others - on the allocation of bile, while showing their own therapeutic effect and in gallstone disease, the third - due to its antispasmodic effect, can greatly ease the condition of 
patients with dyskinesia of the bile ducts. Some medicinal plants with choleretic (or cholespazmodic action on the bile ducts) have a bacteriostatic or bactericidal effect - so they can be used as an auxiliary agent in the treatment of cholangitis and cholecystitis [3, 4].

Therefore, it is important in the application of plant hepatoprotectors to determine not only their indications for applications and therapeutic properties, but also the consideration of contraindications and side effects in the application, age limits and peculiarities of application, in particular, in pediatrics.

\section{Analysis of recent studies and publications in which a solution of the problem and which draws on the author}

In modern scientific literature there are presented studies on the choice of hepatoprotectors. Thus, in the work [5] for choosing a hepatoprotector it is recommended to take into account a number of factors:

- the presence or absence of cholestasis;

- expression of the inflammatory process in the liver (cytolysis syndrome - elevation of ALT, ACAT);

- establishment of the etiological factor of the disease;

- achievement of antifibrotic effect;

- presence of concomitant diseases of the biliary system, improvement of digestive processes.

Principal point of view of authors [6] is the definition of a phased approach to hepatoprotective therapy with the formation of priority selection of a particular drug, depending on the stage of chronic liver disease. Thus, the authors distinguish the following stages of hepatoprotective therapy:

I. Initial stage - aimed at emergency "prosthetics" of metabolic processes of the liver and relief of major clinical and biochemical syndromes.

II. The basis phase - primarily involves the prevention of the development and treatment of fibrosis and cirrhosis of the liver.

III. Supporting stage - is determined by the main pathogenetic syndrome, which is not localized in the previous stages and is associated with clinical conditions. The purpose of this stage is the selective "prosthetics" of the metabolic functions of the hepatocytes that have not been restored. This stage is carried out prolonged (sometimes indefinitely) or as needed.

\section{Allocation of unsolved parts of the general problem, which is dedicated to the article \\ The above publications do not provide infor-} mation on the choice of hepatoprotectors of plant origin, which are a sufficiently large group of drugs and represent more than half of all available hepatoprotectors in the pharmaceutical market. Among the popular medicinal plants and preparations based on them (mono- and multicomponent) are the silybum marianum, the artichoke, and the fumarium officinalis which contains as the main groups of active substances flavonoids, hydroxycholic acids and alkaloids, respectively. Although, in fact, the range of medicinal plants (and groups of biologically active substances) used for the prevention and treatment of diseases of the hepatobiliary system is much wider. This, in our opinion, necessitates the development of methodological grounds for the substantiation of the choice of medicinal plants and phytopreparations in diseases of HBS and determining the aspects of their rational use.

\section{Formulation of goals (tasks) of the article}

The purpose of the work was to develop methodological bases for substantiating the choice of medicinal plants and phytopreparations in diseases of the HBS and determining the aspects of their rational use.

6. Statement of the basic material of the study (methods and objects) with the justification of the results

When choosing a strategy for treatment of diseases of the hepatobiliary system and the prescriping of hepatoprotective agents of plant origin, the first priority is to identify the etiological factors of the disease, the main among which are eating disorders, stress, alcohol abuse, smoking, infection, hereditary factors [7, 8].

The next step is to identify the pathogenetic parts of the disease for the purpose of prescribing drugs with a certain spectrum of pharmacological action, which will contribute to the restoration of the physiological functioning of the affected organ (or organs) [8].

Undoubtedly important in the appointment of therapy is the definition and consideration of contraindications for the use of medicinal products (Fig. 1).

Therapeutic properties and pharmacological actions of medicinal plants used in the treatment of diseases of the liver and bile ducts are determined by biologically active substances (BAS) containing medicinal plants and the predominant content of certain groups of BAS, responsible for one or another pharmacological effect, active substances (Fig. 2).

Among the most common hepatoprotectors of plant origin should be noted preparations of the silybum marianum (Fig. 3) [9].

Bioflavonoids are easily oxidized and, when in contact with free radicals, form small active compounds that cannot support the chain reaction of peroxidation of lipids. In addition, silybum flavonoids contribute to the accumulation of natural antioxidant glutathione in hepatocytes. This ensures the stabilization of hepatocyte membranes, limiting the damaging effects of adverse factors and maintaining the integrity of the liver cells. The membrane-stabilizing effect of silybum flavonoids is also due to the fact that silibinin directly interacts with hepatocyte membranes [10]. Silymarin also activates metabolism in the liver, which results in the normalization of proteinuria of the liver, increased regeneration of hepatocytes and the restoration of their functions. Silybinin stimulates RNA polymerase in the cellular nucleus, which activates transcription and speed of RNA synthesis in liver cells, increases the amount of ribosomes and activates the biosynthesis of structural and functional proteins [11]. 


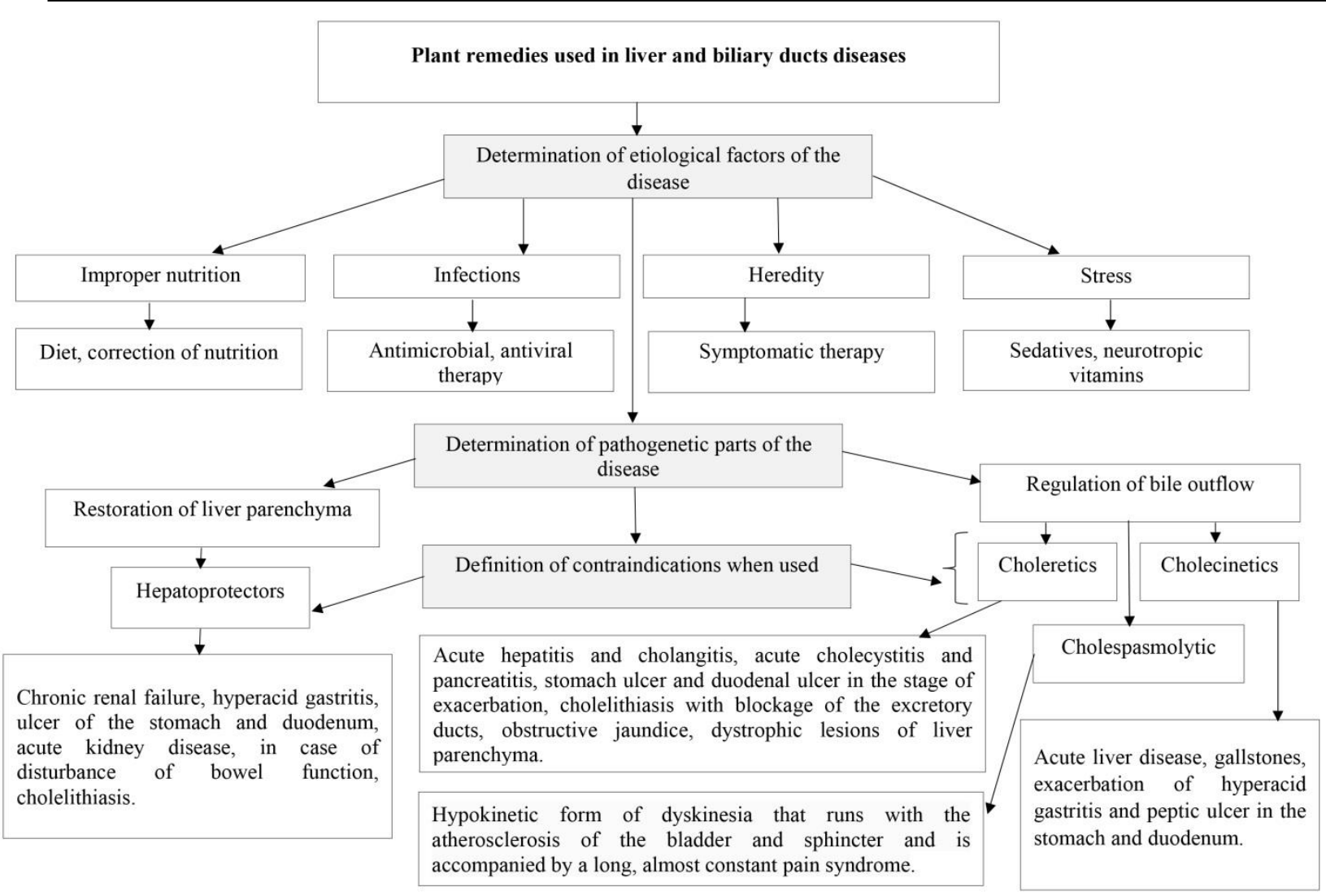

Fig. 1. Algorithm of choice of medicinal plant raw material in diseases of the liver and bile ducts

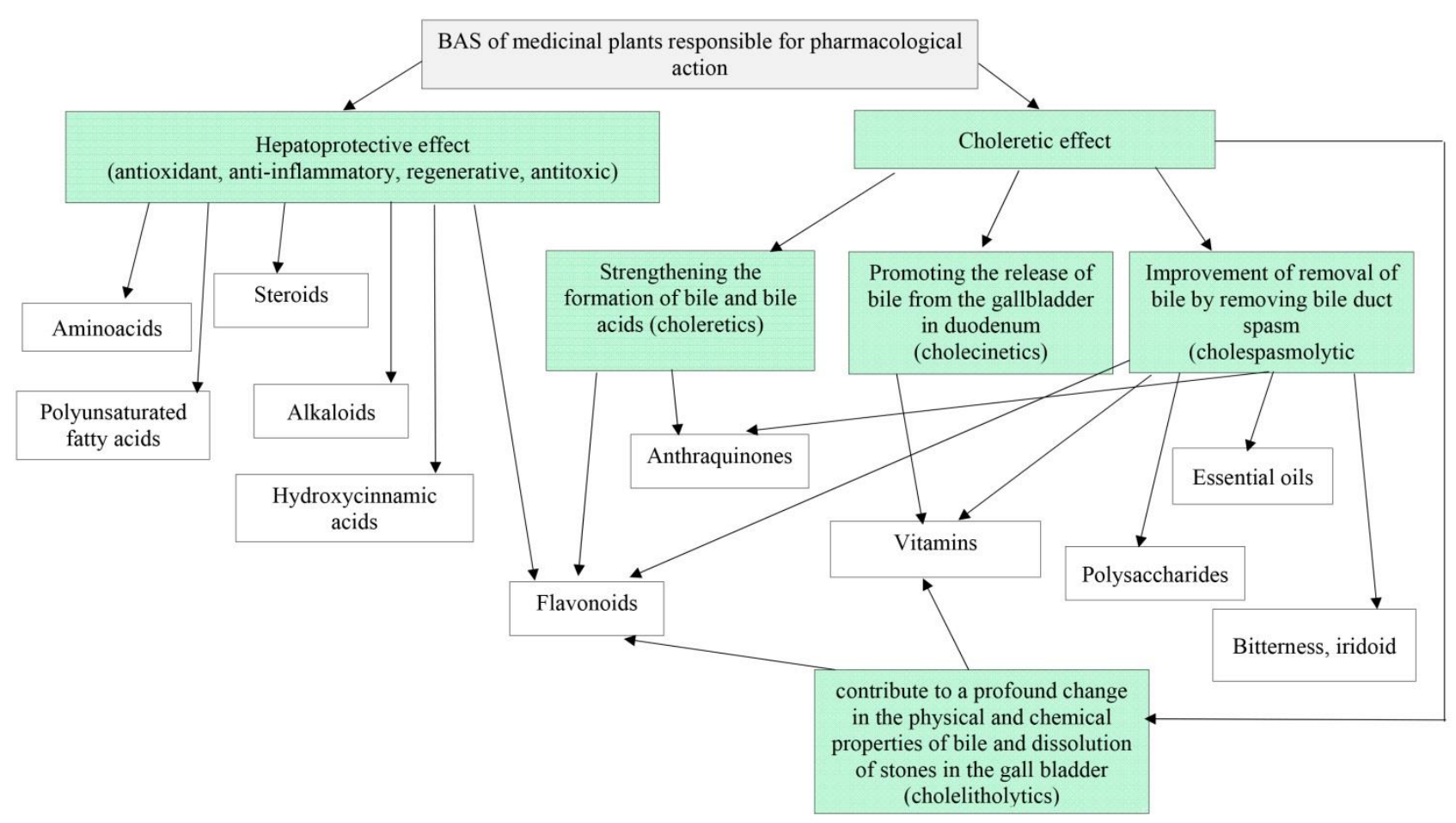

Fig. 2. BAS of medicinal plants responsible for pharmacological action 


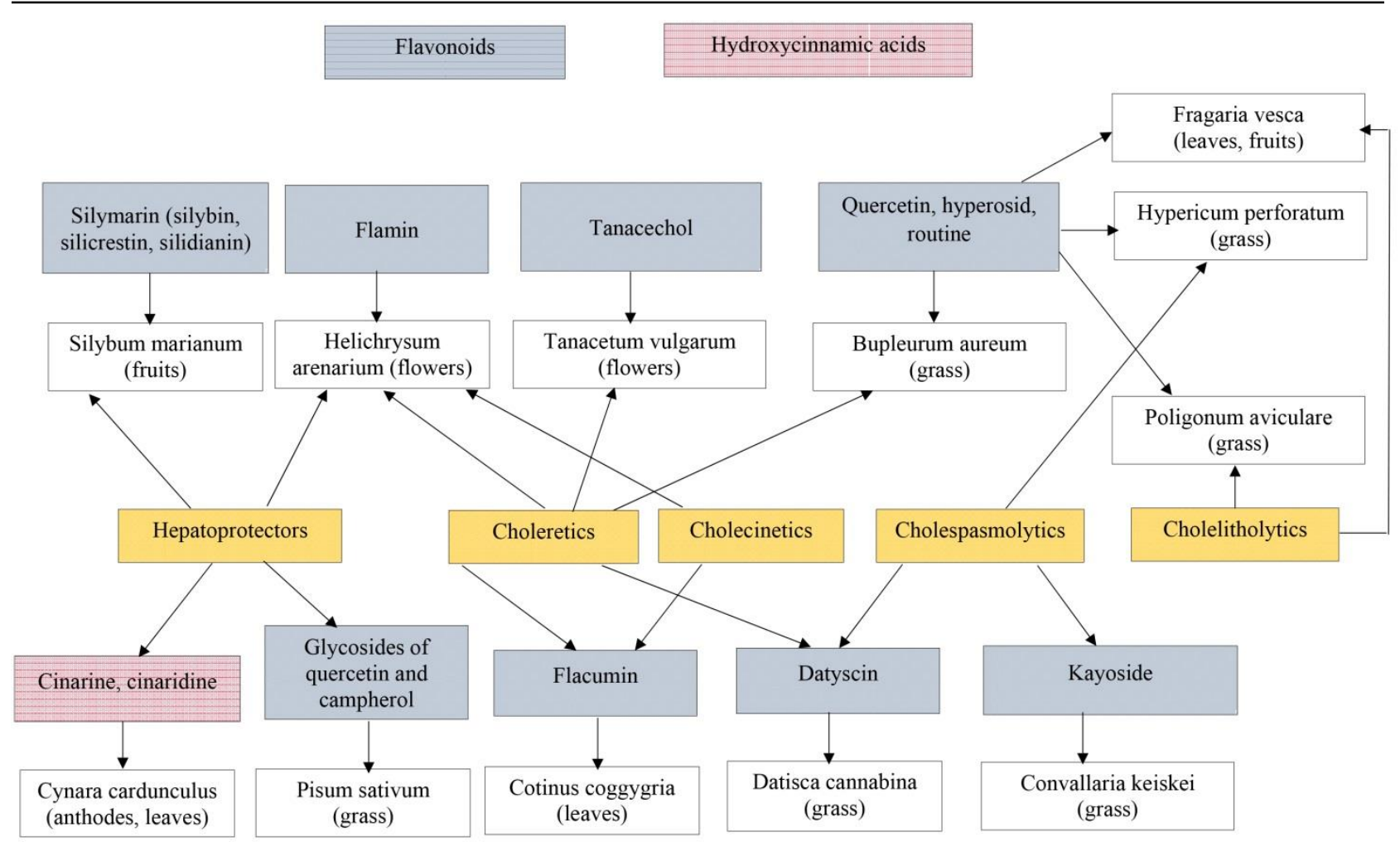

Fig. 3. Medical plants raw material, containing flavonoids and hydroxycinnamic acids

In the development of the drug effects of the drug on the basis of sylibum marianum, it is important both to reduce the synthesis of collagen and to stabilize hepatocyte membranes.

The hepatoprotective effect of artichokes is due to a significant concentration BAS in the plant with antioxidant activity (flavonoids, cinarin, organic acids, etc.) (Fig. 3, Fig. 7). Drugs improve detoxicant function of the liver, exhibit choleretic effect. The components of the extract from fresh artichoke leaves - ascorbic acid, carotene, B vitamins, inulin - normalize metabolic processes, contribute to lowering serum cholesterol and normalizing lipid metabolism, which is also used in atherosclerosis. Artichoke preparations provide a diuretic effect, promote the excretion of urea from the body, toxins (including nitro compounds, alkaloids, metals), in connection with which are shown in chronic renal insufficiency $[12,13]$.

Among the medicinal plants containing flavonoids, the attention is paid to the bupleurum aureum, a plant that has not been fully investigated in our region, but is known for its healing properties in diseases of the hepatobiliary system [14]. The plant is also characterized by the content of sterols (stigmasterol, $\alpha$-spikostylol), which are involved in the formation of therapeutic action.

Biologically active substances of the fumaria officinalis (Fig. 4), primarily alkaloid fumarin, normalize the function of biliary tract (with violations both in hyper and in the hypokinetic type), restore their drainage function, preventing the development of stagnation of bile and the formation of concrements in the gall bladder and biliary tract (the latter is important after cholecystectomy). Fumarin exhibits antispasmodic and restorative effect, strengthens the secretion of the stomach glands.

Among the alkaloids-containing medicinal plants, the Salsola collina [15] deserves attention and detailed study, the main active substances of which are also aminoacids (Fig. 6) and polysaccharides (inulin) (Fig. 7).

Choleretics activates the external liver function and increase the allocation of bile into the duodenum [16]. They are conventionally divided into:

- choleretics - increase the secretion of bile from hepatocytes;

- cholecinetics - promote the allocation of bile in the intestine;

- cholespasmolytics - improve the removal of bile due to the removal of bile duct spasm;

- cholelitholytics - contribute to a profound change in the physical and chemical properties of bile and dissolution of stones in the gall bladder.

Some choleretics simultaneously enhance the formation and allocation of bile. It is difficult to classify medicinal plants for the predominant influence on the liver and bile ducts [17].

Choleretic drugs are divided into true choleretics (affect the secretory mechanism of bile formation) and hydrochloric acid (increasing the amount of bile mainly due to an increase in its content of water) [18]. The group of true choleretics among the herbal means include drugs based on the helichrysum flowers, zeae maydis styli cum stigmatis, the roots of berberis, etc. Natural choleretics contain essential oils, resins, flavonoids, phytosterols, etc. Today there are more than 100 plants, which preparations can be used as choleretic. They directly stimulate metabolic and synthetic processes in hepatocytes, synthesis of bile acids, cholesterol, bilirubin and other organic bile compounds. Herbal preparations, in addition to choleretic action, normalize and stimulate the secretion of the stomach, pancreas, increase the enzymatic activity of gastric juice, have antimicrobial (tanace- 
tum, peppermint), anti-inflammatory (rosae, helichrysum) action, reveal cholespasmolytic (helichrysum, zeae maydis, peppermint) and cholecinetic (tanacetum, petroselinum, berberis) activity, reduce the viscosity of bile (helichrysum, zeae maydis) and increase the content of cholates in it (rosae).

\section{Alkaloids}

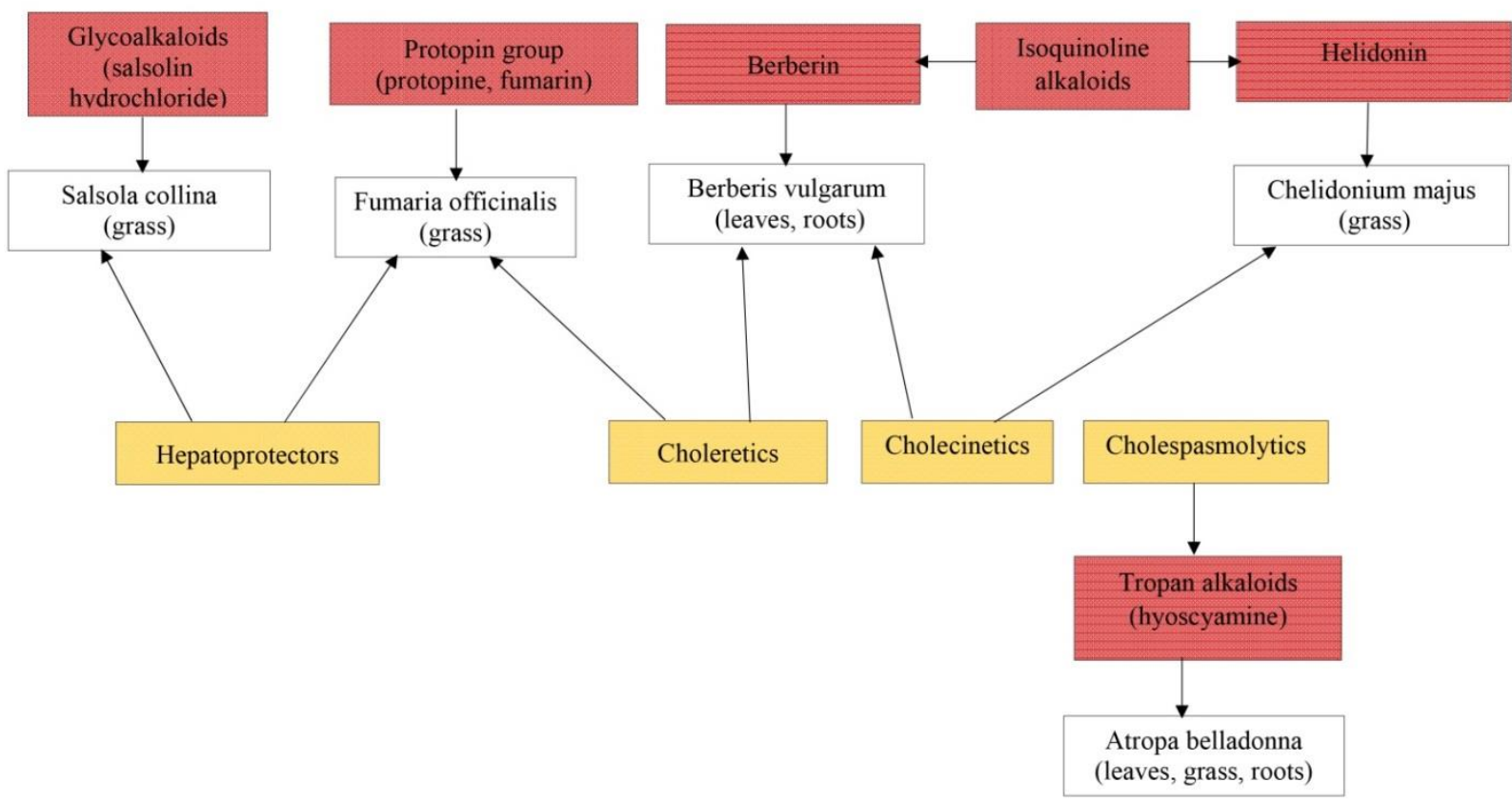

Fig. 4. Medicinal plant raw materials containing alkaloids

Secretion of bile (its water component) increase salicylates, preparations of valerian. In fig. 3 there are medicinal plants containing flavonoids and hydroxycoric acids. Indications for the use of choleretics are inflammatory and functional diseases of the liver, gall bladder and bile ducts in the phase of declining exacerbation or remission (chronic hepatitis, cholecystitis, cholangitis, etc.). In this case, true choleretics can also be prescribed to patients with gallstone disease. The use of choleretics improves the secretion of bile acids. In the presence of inflammatory, infectious processes in the liver, gall bladder or bile ducts in treatment, in addition to choleretic drugs, broad-spectrum antibiotics and modern chemotherapeutic agents should be included.

Choleretics also include medicinal plants containing alkaloids (berberis vulgaris, fumaria officinalis) (Fig. 4), essential oils (anethum graveolens, melissa officinalis) (Fig. 5), anthraquinones (rhamnus frangula, cassia acutifolia) (Fig. 5 )

Cholecinetic drugs, distributed by the content of active substances and presented in fig. 3-5, can act either by stimulating the contraction of the gall bladder and relaxing the Ophi sphincter (cholecinetics), or by reducing the tonus of the gall bladder, biliary tract and sphincter of Oddi (cholecinetics). Indications for the use of cholecinetics is a hypotonic form of dyskinesia of the biliary tract, duodenal sensing.

Indications for the use of plant cholespasmolytics (Fig. 3-5) are the hyperkinetic form of biliary dyskinesia, gallstone disease. Phytotherapeutic agents with choleretic action taken in 15-30 minutes before eating cause active ejection both parenchymatous and gallbladder bile into the duodenum, with this release approximately coinciding in time with the moment of receipt in it of the first portions of food. Thus, there is activation of not only the activity of the liver, but also digestion in general. In addition, most choleretics contain essential oils and other BAS that directly stimulate all digestive glands.

The therapeutic action of most herbal preparations used in liver pathology is aimed at reducing damage and liver fibrosis, correction of dyskinesia of the biliary tract.

Essential oil plants are widely used in the treatment of diseases of the liver and biliary tract (Fig. 5). Essential oils have a weak irritant effect, and, therefore, stimulate the evacuation of bile, as well as relieve spasm of the biliary tract. Essential oils are active metabolites of metabolic processes, have antimicrobial, antiinflammatory and antispasmodic effects, which is especially important for spasticity of biliary tract [2].

The mechanism of action of herbal preparations consists, in particular, in direct stimulation of the secretory function of hepatocytes (for example, essential oils of juniper, anethum, coriandrum, origanum, carum), an increase in the osmotic gradient between the bile and blood, and the increase in the flow of bile ducts of water and electrolytes, stimulation receptors of the mucous membrane of the small intestine, which promotes the activation of the autocrine system of regulation and enhancement of the formation of bile. 
In the treatment of the liver and bile ducts also used plants with bitters (iridoids) (Fig. 6). Iridoids (for example, taraxacum and millefolium) cause reflex enhancement of cholecystokinin release, and, consequently, increase bile excretion. In chronic cholestatic hepatitis, the main focus should be on identifying and eliminating the cause of cholestasis.

The mechanism of choleretic effect consistently include irritation of the mucous membrane of the duo-

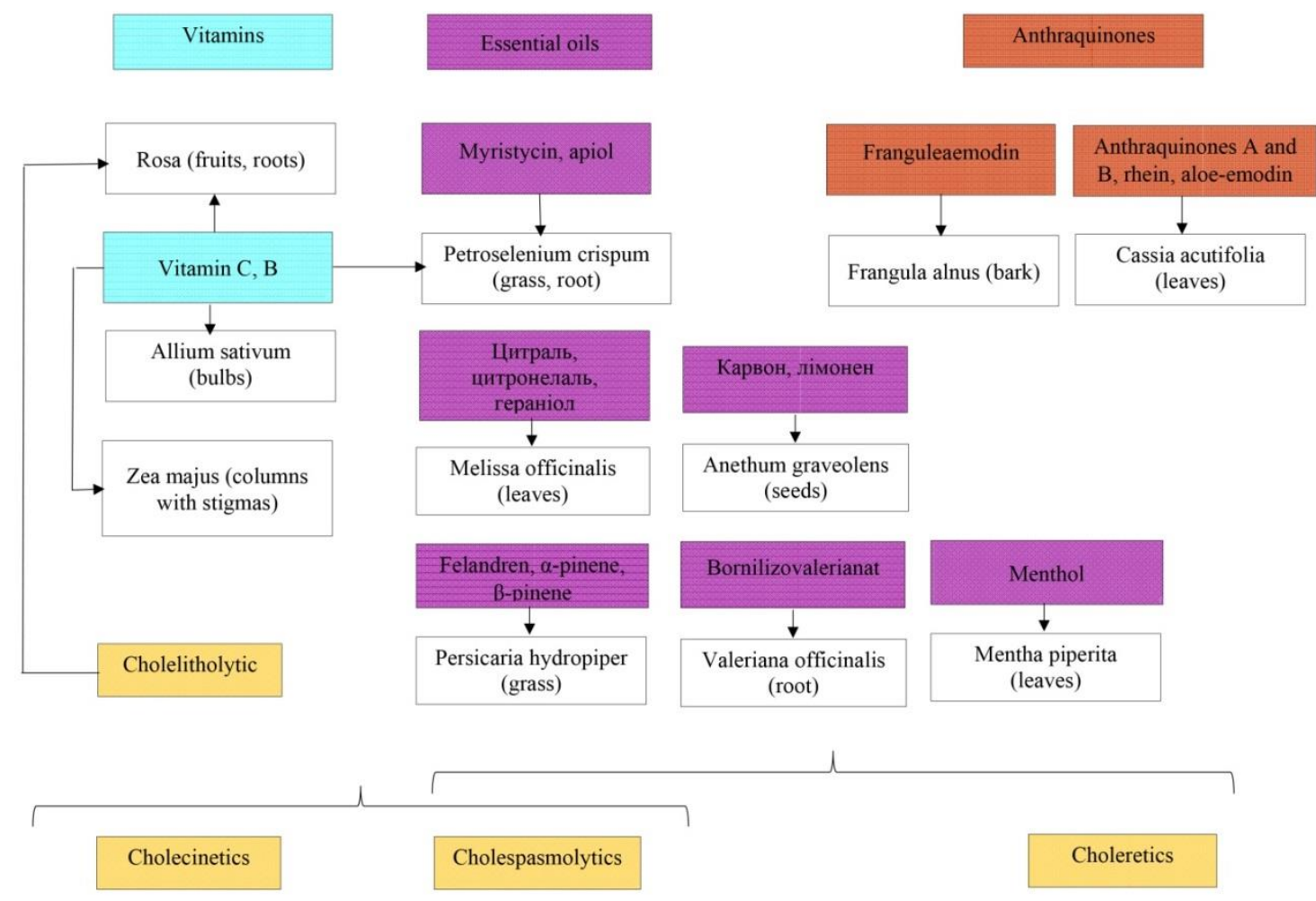

Fig. 5. Medicinal plant raw materials containing vitamins, essential oils, anthraquinones

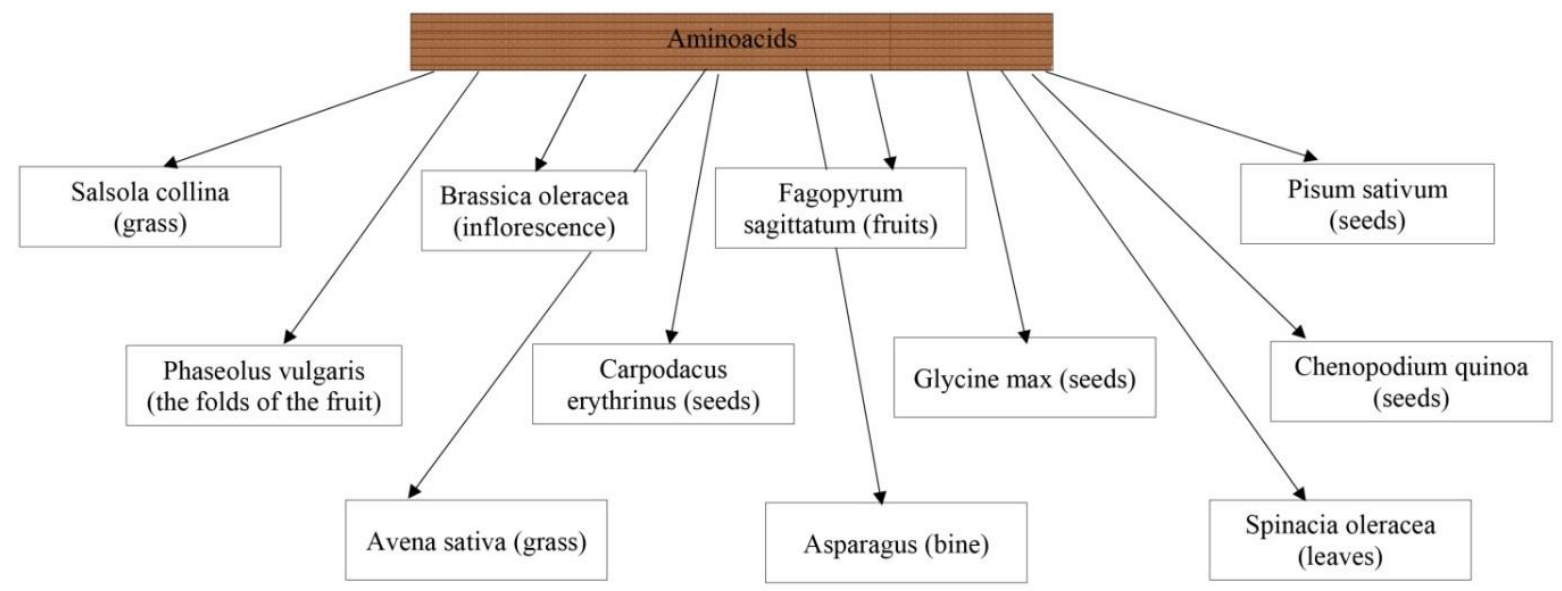

Hepatoprotectors

Fig. 6. Medicinal plant raw materials containing aminoacids

denum, release of cholecystokinin, the latter causes the reduction of the gall bladder and simultaneously relaxes the sphincter of the hepatic pancreas ampoule [2]. The spasmolytic action of flavonoids is myotropic in nature.

Choleretic plants improve bile duct function of the liver, enhance the excretory function of the gall bladder and bile ducts. Thus, and in this case, phytotherapy affects the pathogenetic links of the disease. 


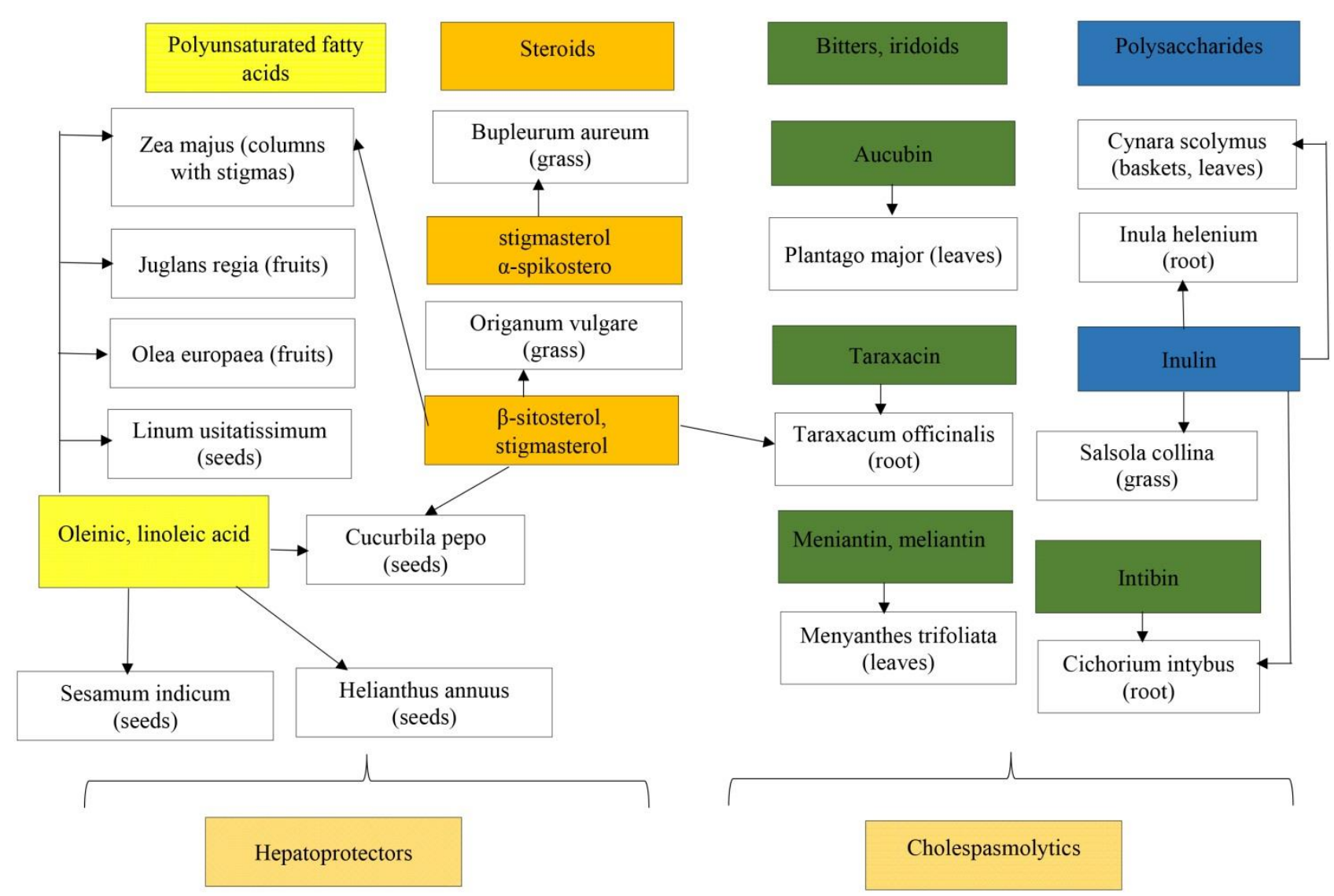

Fig. 7. Medicinal plant raw materials containing polyunsaturated fatty acids, sterols, iridoids, polysaccharides

Magnesium ions, which are part of herbal medicines, can stimulate the secretion of cholecystokinin by the epithelial cells of the duodenum, with which cholecinetic effects of arnica, betulae, helichrysum, rosae and anethum are likely to be associated.

When plants with different mechanisms of cholecinetic effect combined the effect is intensified. In addition to choleretic activity, many plants have antimicrobial, anti-inflammatory, antihypoxic effects and hepatoprotective properties.

At present, hepatoprotectors are used in the integrated therapy of liver diseases [19]. To hepatoprotector include also various herbal products, which have a therapeutic effect in diseases of the liver. Among them the most well-known are various medicinal forms of silybum marianum, helidonium, fumarium, artichoke, chicory, millefolium, cassia, and others. (Fig. 3, 4, 6, 7).

Aminoacid preparations (Fig. 6) are mainly donators of thiol compounds (methionine, ademetionin). Due to the labile methyl group, methionine is involved in the transmethylation reactions that underlie the synthesis of choline, creatine, in the disinfection of various toxic substances. Methionine has a pronounced lipotropic effect, prevents fatty liver infiltration, normalizes the synthesis of lecithin necessary for the formation of lipoproteins in the liver. Increases the number of phospholipids in hepatocyte membranes, normalizes their permeability, and accordingly - intensifies metabolism, exchange of components of the antioxidant system of the liver (increases the level of glutathione), exhibits hypocholesterolemic activity.

Phytotherapy of gallstone disease is aimed at reducing inflammation in the bile ducts and in the gallbladder, improving the bile output, eliminating metabolic disturbances, destroying small stones, and the effect on concomitant diseases. For the treatment are used: flowers of chamomile, leaves of salvia, leaves of betula, flowers of arnica, leaves of berberis, leaves of plantago, grass of artemisia, rhizomes of acorus, fructus of rosa, grass of polygonum, fruits of carum, stigmata maydis, flowers of tanacetum, thymus, etc.

The dissolution of stones is facilitated by the polygonum aviculare, the leaves of fragaria vesca, the roots rosa majalis, and others.

Medicinal plants according to the mechanism of action can be divided into the following groups:

1. Medicinal plants that stimulate bile formation: helichrysum, millefolium, calendula, corn stalks, peppermint, roots and grass of taraxacum, rosa, betula leaves and buds, raphanus, oats, juniper, fragaria vesca, cranberries (leaves), centarium , hypericum, watermelon, grapes, quince, pomegranate, heledonium, tanacetum, linaria vulgaris.

2. Medicinal plants of anti-inflammatory action: hypericum, frangula, chamomile, millefolium, urtica, carota, cabbage, arnica, betula buds, tanacetum, anethum, parsley.

3. Medicinal plants used for biliary dyskinesia of hypertonic type: valerianum, belladonna, amygdalarum, 
chamomile, chaga, hypericum, betula leaves and buds, origanum, berberis, anisum vulgarum.

4. Medicinal plants used for biliary dyskinesia of hypotonic type: peppermint, thymus serpulum, origanum, helichrysum, tanacetum, leaves and seeds of parsley, oil (corn, olive, sunflower seeds).

5. Findings from the research and prospects of further development of this area

Based on scientific information about aetiology, the main parts of the pathological process and the main clinical and biochemical syndromes of diseases of the hepatobiliary system, the main directions of treatment of these diseases with plant products are presented. The values and directions of application of medicinal plants of hepatoprotective action and choleretic action are given; features of the use of medicinal plants with choleretic, cholecinetic, cholespazmolytic and cholelitholytic properties are presented. The necessity of the development of methodological grounds for the substantiation of the choice of medicinal plants and phytopreparations in diseases of the hepatobiliary system and determination of aspects of their rational application is substantiated.

The main principles of the use of medicinal plants in diseases of the liver and bile ducts are formulated.

\section{References}

1. Filippova O. Yu. Mozhlyvosti fitoterapii u likuvanni nealkoholnoi zhyrovoi khvoroby pechinky // Suchasna hastroenterolohiia. 2011. Issue 2 (58). P. 116-122.

2. Hrytsyk A. R., Huzko N. M., Posatska N. M. Poshuk likarskykh roslyn, yaki zastosovuiutsia dlia likuvannia zakhvoriuvan hepatobiliarnoi systemy // Fitoterapiia. 2007. Issue 2. P. 47-51.

3. Mierkulov R. Mozhlyvosti fitoterapii v likuvanni khronichnykh zakhvoriuvan pechinky ta zhovchovyvidnykh shliakhiv // Zdorov'ia Ukrainy. 2017. Issue 24. P. 39.

4. Mubarakshina O. A. Gepatoprotektory: sravnitel'naya kharakteristika i aspekty klinicheskogo ispol'zovaniya // Meditsinskiy vestnik. 2008. Issue 34. P. 51-55.

5. Busalaeva E. I., Tarasova L. V., Matveeva T. S. Gepatoprotektory v klinicheskoy praktike. Algoritm vybora // Zdravookhranenie Chuvashii. 2015. Issue 2. P. 56-64.

6. Mekhtiev S. N., Okovityi S. V., Mekhtieva O. A. Printsipy vybora gepatoprotektorov v praktike terapevta // Lechashhiy vrach. 2016. Issue 8. P. 44-53.

7. Baykova I. E., Nikitin I. G. Lekarstvennoe porazhenie pecheni // Russkiy meditsinskiy zhurnal. 2013. Issue 2. P. 7-15.

8. Morozov S. V., Kucheryavyi Yu. A. Gepatoprotektory v klinicheskoy praktike: ratsional'nye aspekty ispol'zovaniya: posobie dlya vrachey. Moscow: 4TE Art, 2011. 28 p.

9. Kramarev S. A. Sovremennye gepatoprotektory v gepatologii // Dytiachyi likar. 2011. Issue 1. P. 5-9.

10. Vovk E. I. Rastoropsha v sovremennoy gepatologii: estafeta pokoleniy iz Drevney Gretsii v nashi dni // Russkiy meditsinskiy zhurnal. 2010. Issue 30. P. 18-37.

11. An Updated Systematic Review of the Pharmacology of Silymarin / Saller R. et. al. // Complementary Medicine Research. 2007. Vol. 14, Issue 2. P. 70-80. doi: 10.1159/000100581

12. Hepatoprotektorni vlastyvosti likarskykh zasobiv, vyhotovlenykh na osnovi artyshoku posivnoho / Mokhort M. A. et. al. // Farmakolohiia i likarska toksykolohiia. 2009. Issue 3 (10). P. 33-37.

13. Sotskaya Ya. A. Vliyanie kombinatsii antralya i artikhola na kontsentratsiyu tsirkuliruyushhikh immunnykh kompleksov $i$ ikh molekulyarnyy sostav v krovi bol'nykh khronicheskim nekal'kuleznym kholetsistitom, sochetannym s khronicheskim virusnym gepatitom S minimal'noy stepeni aktivnosti v periode meditsinskoy reabilitatsii // Ukrainskyi medychnyi almanakh. 2009. Vol. 12, Issue 1. P. 12-19.

14. Glushchenko A. V., Georgiyants V. A., Perekhoda L. A. Docking studies of the chemical components of the composition of Bupleurum aureum plant in relation to hepatoprotective biotargets // Der Pharma Chemica. 2015. Vol. 7, Issue 4. P. $201-206$.

15. Application of molecular docking for studying the hepatoprotective activity of Hill-growing Saltwort Herb / Glushchenko A. V. et. al. // Journal of Chemical and Pharmaceutical Research. 2015. Issue 7 (3). P. $2219-2223$.

16. Zhuravleva L. V., Krivonosova E. M. Sravnitel'naya kharakteristika gepatoprotektornykh sredstv: klyuch k ratsional'nomu primeneniyu // Sovremennaya gastroenterologiya. 2013. Issue 4 (72). P. 93-101

17. Tkach S. M. Effektivnost' i bezopasnost' gepatoprotektorov s tochki zreniya dokazatel'noy meditsiny // Zdorov'e Ukrainy. 2009. Issue 6. P. 7-10.

18. Eritsland J. Safety considerations of polyunsaturated fatty acids // The American Journal of Clinical Nutrition. 2000. Vol. 71, Issue 1. P. 197-201. doi: 10.1093/ajen/71.1.197s

19. Morozov S. Yu. Gepatoprotektory v praktike vracha-klinitsista // Russkiy meditsinskiy zhurnal. 2009. Issue 1. P. 4-9.

Дата надходження рукопису 15.03.2018

Alla Glushchenko, PhD, Associate Professor, Department of Quality, Standardization and Certification of Medicines, National University of Pharmacy, Pushkinska str., 53, Kharkiv, Ukraine, 61002

E-mail: allaglushchenko05@gmail.com

Inna Vladymyrova, Doctor of Pharmaceutical Sciences, Associate Professor, Department of Pharmacognosy National University of Pharmacy, Pushkinska str., 53, Kharkiv, Ukraine, 61002

E-mail: inna.vladimirova2015@gmail.com

Victoriya Georgiyants, Doctor of Pharmaceutical Sciences, Professor, Head of Department, Department of Pharmaceutical Chemistry, National University of Pharmacy, Pushkinska str., 53, Kharkiv, Ukraine, 61002

E-mail:vgeor@ukr.net 